\title{
Iron tolerance in rice: an efficient method for performing quick early genotype screening
}

\author{
Adriana Pires Soares Bresolin ${ }^{1}$, Railson Schreinert dos Santos², Roberto Carlos Doring Wolter ${ }^{3}$, \\ Rogério Oliveira de Sousa ${ }^{3}$, Luciano Carlos da Maia ${ }^{2}$ and Antonio Costa de Oliveira ${ }^{2^{*}}$ (D)
}

\begin{abstract}
Objectives: This study was conducted to establish a method for early, quick and cheap screening of iron excess tolerance in rice (Oryza sativa L.) cultivars.

Results: Based on the experiments, iron excess leads to reduction in shoot length (SL) and this can be a useful characteristic for adequate screening of tolerant genotypes. The sensitive genotypes Nipponbare and BR-IRGA 409 indicated higher accumulation of iron in their tissues while BRS-Agrisul and Epagri 108 also accumulated iron, but at lower concentrations. BR-IRGA 410 displayed an intermediate phenotype regarding iron accumulation. No changes in shoot Cu content can be observed when comparing treatments. On the other hand, an increase was seen for $\mathrm{Zn}$ and $\mathrm{Mn}$ when shoots are subjected to $\mathrm{Fe}^{2+}$ excess. Fe stress at a lower concentration than $7 \mathrm{mM}$ increased $\mathrm{Zn}$ but decreased Mn contents in shoots of BR-IRGA 409. Strong positive correlations were found here for Fe $\times$ Zn (0.93); Fe $\times M n(0.97)$ and $Z n \times M n$ (0.92), probably due to the Fe-induced activation of bivalent cation transporters. Results show that genotypes scored as sensitive present higher concentration of Fe in shoots and this is an efficient method to characterize rice cultivars regarding iron response.
\end{abstract}

Keywords: Lowland rice, Iron toxicity, Hydroponic culture, Efficient method

\section{Introduction}

Rice (Oryza sativa L.) is an important cereal used to feed more than two-thirds of the worlds population, being the source of more than $20 \%$ of the calories consumed by humankind [1]. In this scenario, Brazil, where rice cultivation represents an important economic activity, is the largest rice producer in the Western hemisphere [2].

One of the major abiotic stresses that affect irrigated rice production and expansion is iron toxicity. Iron (Fe) is an essential nutrient for plant metabolic processes such as respiration and photosynthesis. However, when in excess, it becomes a highly toxic element [3-5]. Even though most world's rice production comes from floodirrigated farms, flooded soils constitute a hypoxic condition which favors the reduction of iron, increasing the concentration of $\mathrm{Fe}^{2+}$ in solution $[5,6]$. Iron excess can cause rusty leaf spots, stained leaf edges, reduction of plant growth, tillering and spikelet fertility. Also, reductions in root system development are observed, which can present dark brown color and stunted growth, with few thick roots. In severe cases, these symptoms associate with yield losses up to $100 \%[7,8]$.

Rice genotypes greatly vary in their response to iron toxicity and the use of tolerant cultivars is one of the effective strategies for preventing yield loss, especially for farmers with low income $[8,9]$.

Considering such background, in this report we aim to evaluate the efficiency of an early, quick and easy method for detection of iron excess tolerance using different rice cultivars.

\section{Main text}

Four Brazilian lowland rice (Oryza sativa L.) genotypes were used in this study. These varieties are recommended by the Southern Brazilian Society of Irrigated 
Rice and are known to be tolerant to iron toxicity by field experiment results [10]: BRS-Agrisul (tolerant), Epagri 108 (tolerant), BR-IRGA 410 (sensitive) and BRIRGA 409 (sensitive). Nipponbare, the Japanese variety used for the first rice genome sequencing project, is reported as sensitive to iron toxicity. Here Nipponbare was used due to its available molecular data and as a reference for comparisons between different studies $[11,12]$.

Seeds were disinfected with $20 \%$ sodium hypochlorite for $10 \mathrm{~min}$, rinsed for three times in ultrapure water and placed in germination paper for $72 \mathrm{~h}\left(25^{\circ} \mathrm{C} ; 16 \mathrm{~h}\right.$ of photoperiod; relative humidity of $100 \%$ ).

Iron stress was performed through the modification of early reports [6]. Seedlings presenting uniform root length were placed in nylon nets fixed on top of plastic pots $(2 \mathrm{~L})$, containing modified nutrient [13]: $40 \mathrm{mg} \mathrm{L}^{-1}$ of $\left(\mathrm{NH}_{4}\right)_{2} \cdot \mathrm{SO}_{4} ; 10 \mathrm{mg} \mathrm{L}{ }^{-1}$ of $\mathrm{KH}_{2} \mathrm{PO}_{4}$; $40 \mathrm{mg} \mathrm{L}{ }^{-1}$ of $\mathrm{KNO}_{3} ; 40 \mathrm{mg} \mathrm{L}{ }^{-1} \mathrm{CaNO}_{3} ; 40 \mathrm{mg} \mathrm{L}^{-1}$ of $\mathrm{MgSO}_{4} \cdot 7 \mathrm{H}_{2} \mathrm{O} ; 0.5 \mathrm{mg} \mathrm{L}{ }^{-1}$ of $\mathrm{MnSO}_{4} \cdot \mathrm{H}_{2} \mathrm{O} ; 0.05 \mathrm{mg} \mathrm{L}^{-1}$ of $\mathrm{Na}_{2} \mathrm{MoO}_{4} \cdot 2 \mathrm{H}_{2} \mathrm{O} ; 0.58 \mathrm{mg} \mathrm{L}-1$ of $\mathrm{NaCl} ; 0.2 \mathrm{mg} \mathrm{L}^{-1}$ of $\mathrm{H}_{3} \mathrm{BO}_{3} ; 0.01 \mathrm{mg} \mathrm{L} \mathrm{L}^{-1}$ of $\mathrm{ZnSO}_{4} \cdot 7 \mathrm{H}_{2} \mathrm{O}, 0.01 \mathrm{mg} \mathrm{L}^{-1}$ of $\mathrm{CuSO}_{4} \cdot 5 \mathrm{H}_{2} \mathrm{O}$ and $2 \mathrm{mg} \mathrm{L}{ }^{-1}$ of $\mathrm{FeSO}_{4} \cdot 7 \mathrm{H}_{2} \mathrm{O}$. Seedlings were kept at $25^{\circ} \mathrm{C}, 16 \mathrm{~h}$ of photoperiod for 28 days, with changing the solution every 7 days.
After this period, the seedlings were subjected to different treatments: Control (T1) with standard nutrient solution $\left(2 \mathrm{mg} \mathrm{L}^{-1}\right.$ of $\mathrm{FeSO}_{4} \cdot 7 \mathrm{H}_{2} \mathrm{O}$ with $\left.\mathrm{pH} 4.0 \pm 0.1\right)$; iron excess (T2) with modified nutrient solution $\left(2000 \mathrm{mg} \mathrm{L}^{-1}\right.$ of $\mathrm{FeSO}_{4} \cdot 7 \mathrm{H}_{2} \mathrm{O}$ with $\mathrm{pH} 4.0 \pm 0.1$ ). Seedlings were kept under these conditions for 3 days. The visual evaluations were performed following the standard evaluation system for rice.

The visual symptoms were based in leaf death and symptom intensity, compared to control (Fig. 1a). The grades ranged from 0 to 9 . Tolerant $(\mathrm{T})$ plants received grades $0-3$, moderately tolerant (MT) $4-5$ and the sensitive (S) 6-9 [14]. After the treatment, root (RL) and shoot (SL) lengths were measured (Fig. 1b). Copper $(\mathrm{Cu})$, zinc $(\mathrm{Zn})$, manganese $(\mathrm{Mn})$ and iron $(\mathrm{Fe})$ contents accumulated in shoots were also evaluated [15].

A completely randomized design in a double factorial $2 \times 5$ (treatment $\times$ genotype) scheme with three replications, where the observation unit consisted on 20 plants per genotype. The data was subjected to analysis of variance (ANOVA) and then to Tukey HSD test and a Pearson's correlation, both with $\mathrm{p} \leq 0.05$. Path analysis was performed as described [16, 17]. Data from path analysis are not completely shown here, but most important results are described. a
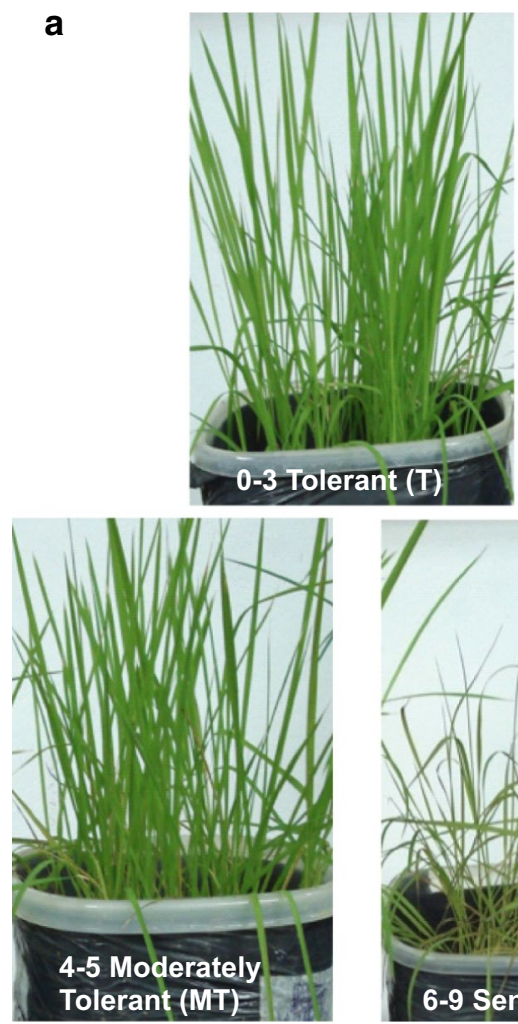

b

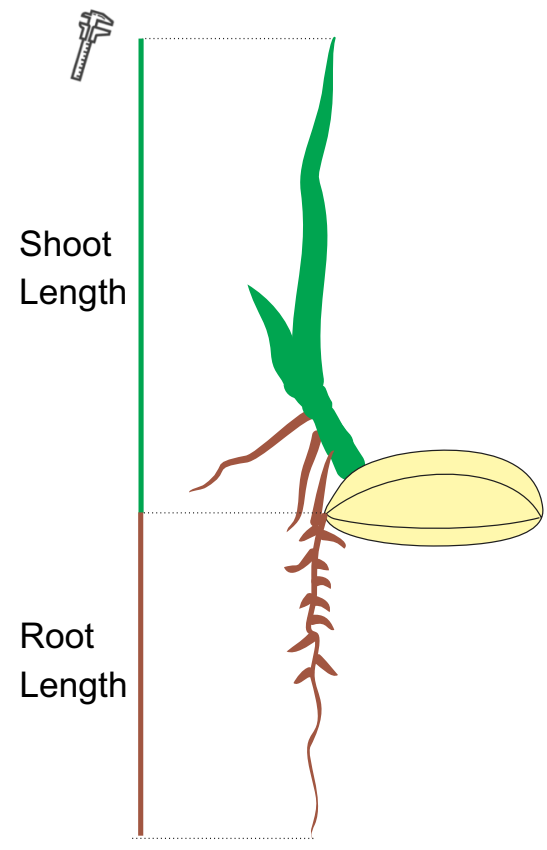

Fig. 1 Information about the evaluation procedures on $\mathbf{a}$ visual symptoms for scoring and $\mathbf{b}$ shoot and root length measurements 
Visual symptoms observed on plants subjected to iron excess toxicity were yellowing, brown spots along the leaves and leaf tip necrosis. The scores based on genotype performance under excess iron are shown on Table 1.

Epagri 108 (tolerant in field conditions) barely presented $\mathrm{Fe}^{2+}$ toxicity symptoms while the genotype BRIRGA 409 (sensitive in field conditions) presented easily identifiable $\mathrm{Fe}^{2+}$ toxicity symptoms under iron excess conditions (T2). These results agree with field assays [10]. Nipponbare presented higher scores, being ranked as sensitive to iron stress, classification in agreement with previous reports obtained in hydroponic systems [12]. The use of bronzing scores, measured in the field or in hydroponic systems, has shown to be efficient on the discrimination of tolerant genotypes, being associated to grain yield $[8,9,18]$. However, since in early developmental stages changes in SL, RL and nutrient accumulation in tissues have been reported to constitute an objective form of evaluation that can be used in conjunction with bronzing scores, these were also evaluated during this study [19-21].

It is shown here that iron excess can lead to reduction in SL (Fig. 2a) and, as other previous studies suggest, this can be a useful characteristic for helping the screening of tolerant genotypes $[19,21]$.

The sensitive genotypes Nipponbare and BR-IRGA 409 indicated higher accumulation of iron in their tissues (Fig. 2b), while BRS-Agrisul and Epagri 108 (both previously characterized as tolerant) also accumulated iron, but at lower concentrations (i.e., ca. $50 \%$ less). It is shown that BR-IRGA 410 display an intermediate phenotype regarding iron accumulation.

It is also shown that BRS-Agrisul (a medium cycle genotype; 121-130 days) accumulated lower amounts of iron than other medium cycle genotypes such as BRIRGA 410 and BR-IRGA 409, showing that the time

\begin{tabular}{|c|c|c|c|c|}
\hline Genotype & LBS1 & LBS2 & LBS3 & Classification \\
\hline Epagri 108 & 2 & 1 & 2 & $\mathrm{~T}$ \\
\hline BRS-Agrisul & 2 & 4 & 3 & $\mathrm{~T}$ \\
\hline BR-IRGA 410 & 5 & 4 & 6 & MT \\
\hline Nipponbare & 7 & 8 & 8 & S \\
\hline BR-IRGA 409 & 6 & 7 & 7 & S \\
\hline
\end{tabular}

The LBS numbers follow a scale from 0 to 9 , adapted from standard evaluation system for Rice used by IRRI

Classification regarding iron tolerance levels, T (tolerant 0-3), MT (moderately tolerant 4-5) and S (sensitive 6-9) from germination to grain production is not the cause of differences in the amount of iron accumulated in tissues.

No changes in shoot $\mathrm{Cu}$ content can be observed when comparing treatments (Fig. 2b). On the other hand, an increase was seen for $\mathrm{Zn}$ and Mn (Fig. 2b) when shoots are subjected to $\mathrm{Fe}^{2+}$ excess (T2). Fe stress at a lower concentration than $7 \mathrm{mM}$ increased $\mathrm{Zn}$ but decreased $\mathrm{Mn}$ contents in shoots of BR-IRGA 409 [22].

Strong positive correlations were found here for $\mathrm{Fe} \times \mathrm{Zn}$ (0.93); Fe $\times \mathrm{Mn} \quad(0.97)$ and $\mathrm{Zn} \times \mathrm{Mn} \quad(0.92)$ (Table 2), probably due to the Fe-induced activation of bivalent cation transporters [23].

Iron content is negatively correlated with SL $(-0.37)$ and RL (-0.42), highlighting the impact that excessive accumulation of this metal has on rice growth and development (Table 2). Although similar results are observed for correlations between $\mathrm{Mn}$ and $\mathrm{Zn}$ with $\mathrm{SL}$ and $\mathrm{RL}$, these are only significant for RL (Table 2) and, according to the path analysis (data not shown), it seems to be an indirect effect of iron accumulation.

This quick and easy modification of the protocol described by [6] proved to be an efficient method to select tolerant Brazilian lowland rice genotypes for iron excess tolerance. Plants showing higher $\mathrm{Fe}^{2+}$ accumulation in shoots (BR-IRGA 409 and Nipponbare) were the same identified as sensitive to $\mathrm{Fe}^{2+}$ by the bronzing score. Besides, the genotype BR-IRGA 409, characterized as sensitive, is the one showing the highest reduction of SL due to iron toxicity. BR-IRGA 410, an intermediate phenotype for shoot $\mathrm{Fe}^{2+}$ accumulation, is characterized as moderately tolerant in symptom score evaluation. BRSAgrisul and Epagri 108 which are the genotypes displaying the lowest $\mathrm{Fe}^{2+}$ accumulation levels in shoots, are characterized as tolerant in visual symptom evaluation.

In Brazil the search for iron tolerant genotypes has been performed for many years. The methods used involve field tests during different years/growing seasons [24]. Even today, this is the most acceptable method, being necessary to have credibility when registering a cultivar. However, for a quick and inexpensive initial selection in breeding programs, efficient protocols to predict genotype performance have not yet been achieved [25]. Different methods have been tested, these include potor tank-based screening procedures that have been presented over time until very recently [26-28].

It is common for the methods tested to find an adequate correlation with the field experiments using soils of the site of interest [29]. The method presented here is useful for an initial selection of genotypes, without considering the soil, since the removal of this from its place of origin does not guarantee perfect reproducibility of 


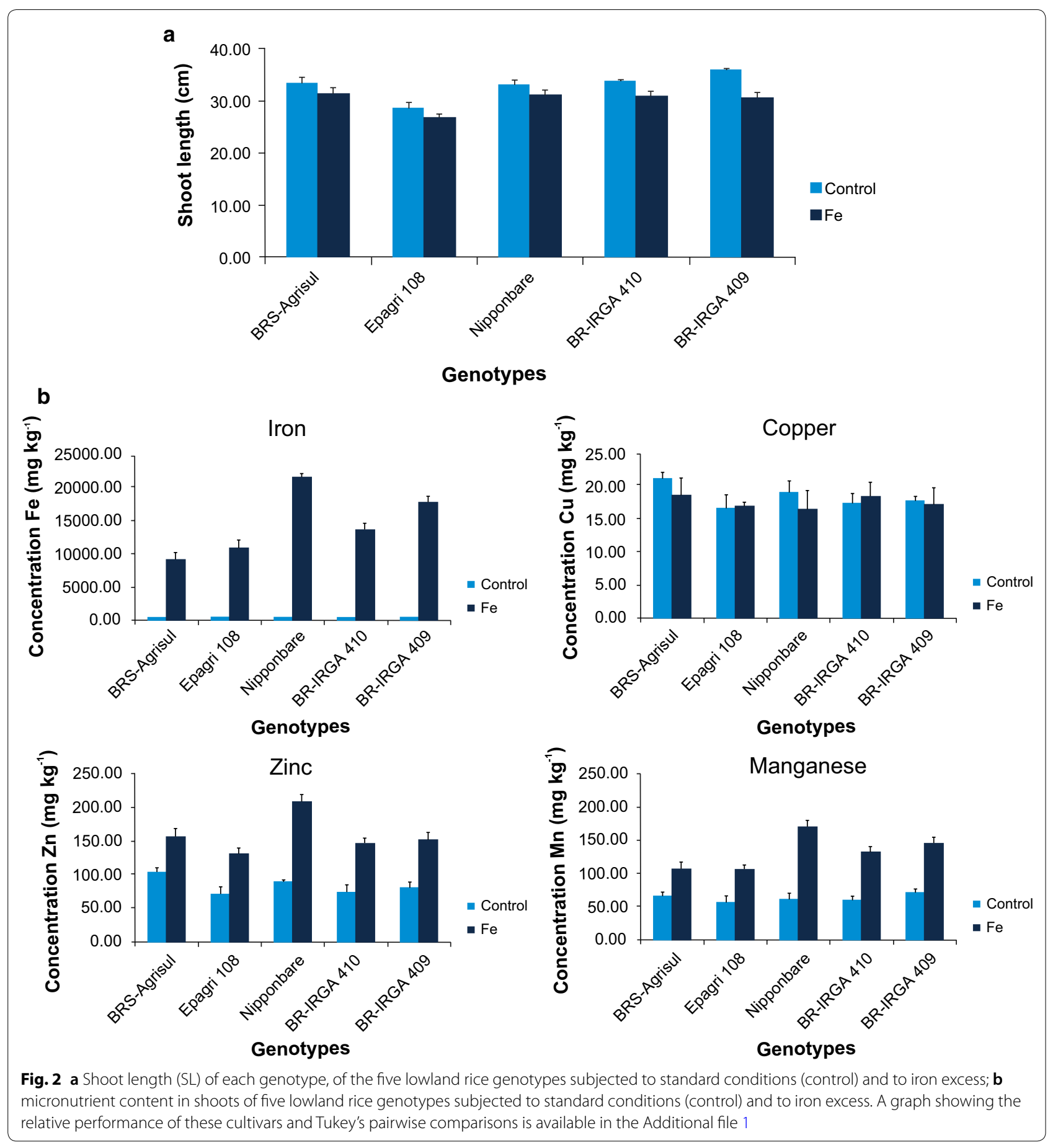

the results, either by the modification of the structure or by the lack of local climatic elements. Thus, a prior soil-independent evaluation can be useful to reduce the number of genotypes to be tested and the cost, taking only the most promising ones to field.

\section{Limitations}

The limitations of this work are the use of just five genotypes. Although they are contrasting for iron response and should be sufficient to explain the responses, it could be considered a limitation. 
Table 2 Pearson's correlation coefficient within and between traits (SL and RL) and micronutrients (iron, copper, zinc and manganese) for five genotypes/varieties under control and iron toxicity conditions in hydroponic culture

\begin{tabular}{lllllll}
\hline Variables & Fe & Cu & Zn & Mn & SL & RL \\
\hline Fe & 1 & -0.19 & $0.93^{*}$ & $0.97^{*}$ & $-0.37^{*}$ & $-0.42^{*}$ \\
$\mathrm{Cu}$ & & 1 & -0.02 & -0.19 & 0.24 & -0.26 \\
$\mathrm{Zn}$ & & 1 & $0.92^{*}$ & -0.27 & $-0.38^{*}$ \\
$\mathrm{Mn}$ & & & 1 & 1 & $-0.49^{*}$ \\
$\mathrm{SL}$ & & & & 0.08 \\
$\mathrm{RL}$ & & & & & 1 \\
\hline
\end{tabular}

* Significant at $p \leq 0.05$

\section{Additional files}

Additional file 1: Figure S1. Relative performance obtained by the division of the values of plants under stress by the values of the control treatment. Columns followed by the same letters do not differ significantly (Tukey's pairwise comparisons, $\mathrm{p}<0.05$ ).

\section{Abbreviations}

ANOVA: analysis of variance; MT: moderately tolerant; RL: root length; S: sensitive; SL: shoot length; T: tolerant; Tukey HSD: Tukey honest significant difference.

\section{Acknowledgements}

Not applicable.

\section{Authors' contributions}

APSB: performed the experiments and wrote the MS; RSS: helped with analyses and to write the MS; RCDW: helped with nutrient analyses; ROS: suggested modifications in the analysis protocols and corrected manuscript; LCM: sought information on field experiments and corrected manuscript; ACO: conceived the idea and corrected the manuscript. All authors read and approved the final manuscript.

\section{Funding}

The financial support was provided by Coordination for the Improvement of Higher Education Personnel (CAPES) (fellowships to graduate students), Research Support Foundation of Rio Grande do Sul (FAPERGS) (fellowships to undergraduates) and The Brazilian National Council for Scientific and Technological Development (CNPq) (grants and fellowships).

\section{Availability of data and materials}

The datasets used and/or analysed during the current study are available from the corresponding author on reasonable request.

\section{Ethics and consent to participate}

Not applicable.

\section{Consent for publication}

Not applicable.

\section{Competing interests}

The authors declare that they have no competing interests.

\section{Author details}

${ }^{1}$ Universidade Federal do Pampa (UNIPAMPA), Itaqui, RS, Brazil. ${ }^{2}$ Plant Genomics and Breeding Center, Universidade Federal de Pelotas, Pelotas, RS, Brazil.

${ }^{3}$ Department of Soils, Universidade Federal de Pelotas, Pelotas, RS, Brazil.
Received: 25 June 2018 Accepted: 5 June 2019

Published online: 25 June 2019

References

1. Wogu MD, Omoruyi MI, Odeh HO, Guobadia JN. Microbial load in readyto-eat rice sold in Benin City. J Microbiol Antimicrob. 2011;3:29-33.

2. Santos CE. Brazilian rice yearbook. Santa Cruz do Sul: Editora Gazeta Santa Cruz; 2015.

3. Santos RS, Krüger MM, Pegoraro C, Madabula FP, et al. Transcriptional regulation of seven ERFs in rice under oxygen depletion and iron overload stress. Trop Plant Biol. 2013;6:16-25.

4. Finatto T, de Oliveira AC, Chaparro C, da Maia LC, et al. Abiotic stress and genome dynamics: specific genes and transposable elements response to iron excess in rice. Rice. 2015:8:1-13.

5. Santos RS, Araujo Júnior AT, Pegoraro C, Oliveira AC. Dealing with iron metabolism in rice: from breeding for stress tolerance to biofortification. Genet Mol Biol. 2017:40:312-25.

6. Asch F, Becker M, Kpongor DS. A quick and efficient screen for resistance to iron toxicity in lowland rice. J Plant Nutr Soil Sci. 2005;168:764-73.

7. Sahrawat KL. Iron toxicity in wetland rice and the role of other nutrients. J Plant Nutr. 2004:27:1471-504.

8. Elec V, Quimio CA, Mendoza R, Sajise AGC, et al. Maintaining elevated $\mathrm{Fe}^{2+}$ concentration in solution culture for the development of a rapid and repeatable screening technique for iron toxicity tolerance in rice (Oryza sativa L.). Plant Soil. 2013:372:253-64.

9. Audebert A, Fofana M. Rice yield gap due to iron toxicity in West Africa. J Agron Crop Sci. 2009;195:66-76.

10. SOSBAI. Sociedade Sul-Brasileira de Arroz Irrigado. Arroz Irrigado: Recomendações técnicas da pesquisa para o sul do Brasil. Pelotas: SOSBAl; 2016. p. 197.

11. International Rice Genome Sequencing Project. The map-based sequence of the rice genome. Nature. 2005;436:793-800.

12. Engel $K$, Asch F, Becker M. Classification of rice genotypes based on their mechanisms of adaptation to iron toxicity. J Plant Nutr Soil Sci. 2012;175:871-81.

13. Yoshida S. Laboratory manual for physiological studies of rice. 3rd ed. Manila: IRRI; 1976. p. 83.

14. IRRI, International Rice Research Institute. Standard evaluation system for rice. Los Banõs: IRRI; 1975.

15. Tedesco MJ. Análises de Solo, Planta e Outros Materiais. 2nd ed. Porto Alegre: Departamento de Solos, Faculdade de Agronomia; UFRGS; 1995.

16. Wright S. Correlation and causation. J Agric Res. 1921;20:557-85.

17. Li CC. Path analysis: a primer. Pacific Grove: Boxwood Press; 1975. p. 346.

18. Chérif M, Audebert A, Fofana M, Zouzou M. Evaluation of iron toxicity on lowland irrigated rice in West Africa. Tropicultura. 2009:27:88-92.

19. Crestani M, da Silva JAG, Souza VQ, Hartwig I, et al. Irrigated rice genotype performance under excess iron stress in hydroponic culture. Crop Breed Appl Biotechnol. 2009;9:85-93. 
20. Quinet M, Vromman D, Clippe A, Bertin P, et al. Combined transcriptomic and physiological approaches reveal strong differences between shortand long-term response of rice (Oryza sativa) to iron toxicity. Plant Cell Environ. 2012;35:1837-59.

21. Onaga G, Egdane J, Edema R, Abdelbagi I. Morphological and genetic diversity analysis of rice accessions (Oryza sativa $\mathrm{L}$ ) differing in iron toxicity tolerance. J Crop Sci Biotechnol. 2013;16:53-62.

22. Müller C, Kuki KN, Pinheiro DT, de Souza LR, et al. Differential physiological responses in rice upon exposure to excess distinct iron forms. Plant Soil. 2015;391:123-38.

23. Palmer C, Guerinot ML. A question of balance: facing the challenges of Cu, Fe and Zn homeostasis. Nat Chem Biol. 2011;5:333-40.

24. EMBRAPA. Anais da I Reunião sobre ferros em solos inundados; 1988.

25. Sikirou M, Saito K, Achigan-Dako EG, Drame KN, Ahanchédé A, Venuprasad R. Genetic improvement of iron toxicity tolerance in rice-progress, challenges and prospects in West Africa. Plant Prod Sci. 2015;18:423-34.

26. Abifarin AO. Progress in breeding rice for tolerance to iron toxicity. In: WARDA, editor. WARDA Annual report for 1990. Bouaké: West Africa Rice Development Association; 1989.
27. Onaga G, Edema R, Asea G. Tolerance of rice germplasm to iron toxicity stress and the relationship between tolerance, $\mathrm{Fe}^{2+}, \mathrm{P}$ and $\mathrm{K}$ content in the leaves and roots. Arch Agron Soil Sci. 2012;59:213-29.

28. Sikirou M. Agro-morphological characterization of lowland rice collection for tolerance to iron toxicity. Abomey-Calavi: Faculty of Agricultural Sciences (FSA); 2009.

29. Sikirou M, Saito K, Dramé KN, Saidou A, Dieng I, Ahanchédé A, Venuprasad R. Soil-based screening for iron toxicity tolerance in rice using pots. Plant Prod Sci. 2016;19(4):489-96.

\section{Publisher's Note}

Springer Nature remains neutral with regard to jurisdictional claims in published maps and institutional affiliations.
Ready to submit your research? Choose BMC and benefit from:

- fast, convenient online submission

- thorough peer review by experienced researchers in your field

- rapid publication on acceptance

- support for research data, including large and complex data types

- gold Open Access which fosters wider collaboration and increased citations

- maximum visibility for your research: over $100 \mathrm{M}$ website views per year

At BMC, research is always in progress.

Learn more biomedcentral.com/submissions 